Paola lamiceli*

\title{
Online Platforms and the Digital Turn in EU Contract Law: Unfair Practices, Transparency and the (pierced) Veil of Digital Immunity
}

https://doi.org/10.1515/ercl-2019-0024

Abstract: The digital revolution has pervaded entire sectors of economy and society, creating new markets and new market intermediaries, able to aggregate massive demand and offer beyond any conceivable thresholds in the offline setting.

The article moves from the recent adoption of the EU/2019/1150 Regulation on fairness and transparency for business users of online intermediation services and the pending reform of several consumer directives under the auspices of the Digital Agenda and the New Deal for Consumers. It focuses on the role of online platforms and addresses two main policy issues: (i) whether EU legislation should go beyond the adaptation of existing rules opting for a sharper turn towards dedicated regulatory tools in the field of digital law, and (ii) whether the digital dimension of trade should lead to revise the current focus on consumer protection and, more broadly, the current divide between BtoC and BtoB law.

Digital private law is taking the first steps into the internal market. Whereas national private law will continue to provide the general framework for private law matters arising in the internet and may certainly contribute to define model rules for ad hoc legislation on digital trade, the EU legislation is due to play a major role and to find new balances between the fundamental freedoms and the protection of digital users. The digital challenge will enable EU institutions to take part in a global venture well beyond the boundaries of the internal market.

Keywords: online platforms, transparency, consumer and business protection, digital private law

Résumé: La révolution numérique a conquis des secteurs entiers de la société et de l'économie, créant de nouveaux marchés et de nouveaux intermédiaires et offrant la capacité d'agréger massivement l'offre et la demande à un degré inconcevable dans le monde réel.

*Corresponding author: Paola lamiceli, University of Trento: Faculty of Law, via Verdi, 53, 38122 - Trento, Italy, E-Mail: paola.iamiceli@unitn.it 
Partant de l'adoption récente du règlement UE/2019/1150 promouvant l'équité et la transparence pour les entreprises utilisatrices de services d'intermédiation en ligne ainsi que de la réforme imminente de diverses directives protectrices des consommateurs sous les auspices de la nouvelle donne pour les consommateurs et la stratégie numérique, cet article se concentre sur le rôle de plateformes numériques et ce faisant envisage deux questions de politique législative, à savoir (1) si la législation de l'UE devrait aller au delà de l'adaptation des règles existantes et opter pour un changement plus net en faveur d'outils de régulation spécifiques dans le domaine numérique, et (2) si la dimension numérique du marché devrait conduire à revoir l'objectif actuel de protection des consommateurs et plus particulièrement la distinction entre les régimes applicables aux rapports entre professionnels et ceux qui impliquent un consommateur.

Le droit privé numérique entre progressivement dans le marché intérieur. Tandis que le droit privé national continuera de fournir le cadre général pour les questions juridiques de droit privé liées à l'internet et servira certainement de modèle à l'occasion pour la régulation du commerce électronique, le droit de l'Union occupera une place importante et devra trouver des équilibres nouveaux entre les libertés fondamentales et la protection des usagers du numérique. Le défi numérique permettra ainsi aux institutions de l'Union de participer à une entreprise globale qui s'étend bien au delà̀ des frontières du marché intérieur.

Zusammenfassung: Die digitale Revolution erfasst ganze Bereiche in Wirtschaft und Gesellschaft, schafft dabei neue Märkte und neue Marktintermediäre und ist fähig, enorme Nachfrage- und Angebotsvolumina zu bündeln, wie dies in der analogen Welt nicht möglich war.

Dieser Beitrag baut auf einer reichen Reformagenda auf EU-Ebene aus, namentlich mit der jüngsten Verabschiedung der EU-Verordnung EU/2019/1150 zu Fairness und Transparenz für gewerbliche Nutzer von Online-Vermittlungsdiensten, mit der bevorstehenden Reform verschiedener EU-Verbraucherrichtlinien und der EU-Digitalagenda und dem "New Deal” für Verbraucher. Auf diesem Hintergrund beleuchtet der Beitrag Plattformen primär unter zwei Blickwinkeln: (i) ob der EU-Gesetzgeber über eine Politik der bloßen Adaption hinausgehen und ein genuines Digitalrecht schaffen sollte, und (ii) ob mit der digitalen Dimension des Handels nicht der Fokus weg vom Verbraucher wandern sollte, also auch von der Trennung zwischen B2C und B2B.

Das Privatrecht des digitalen Raums nimmt langsam Einzug in die Binnenmarktregeln. Während nationales Privatrecht weiterhin das Rahmenwerk für Privatrechtsfragen im Internet bereitstellen und sicherlich auch hilfreich bei der Adhoc-Entwicklung von Rechtssetzungsmodellen sein wird, wird dem EU-Gesetzgebung zwangsläufig eine gewichtigere Rolle zukommen. Es wird ein neues Gleich- 
gewicht zwischen Grundfreiheiten und den Nutzern digitaler Angebote zu finden sein. Die digitale Herausforderung wird es den EU-Institutionen umgekehrt erlauben, die globalen Entwicklungen deutlich über den Binnenmarkt hinaus zu beeinflussen.

\section{The Digital Revolution and the Challenges for European Private Law}

The digital revolution has not only deeply affected human behaviour in the way we address daily needs. It has pervaded entire sectors of economy and society, radically changing the modes of financing, making investments, developing new businesses, sourcing and marketing products and services, purchasing almost any tradeable object. It has created new markets and new market intermediaries, able to aggregate massive demand and offer beyond any conceivable thresholds in the offline setting. ${ }^{1}$

From a private law point of view, the digital revolution is a treasure trove of challenges. Information is the essence of any digital-related activity: reconciling accessibility with intellectual property concerns, on the one side, and privacy on the other side, is among the most critical issues generated by the use of internet technologies. ${ }^{2}$ Well beyond the realm of information, new forms of property rights are emerging, where the collective dimension largely outclasses the individual soul of traditional ownership. ${ }^{3}$ The very essence of contract changes, making even more blurred the idea of a mutual commitment based on the meeting of the minds; ${ }^{4}$ unilateral commitments and various forms of reliance gain space along

1 UNCTAD, Trade and Development Report 2018, Power, Platforms and the Free Trade Delusion (New York and Geneva: United Nations, 2018) 69.

2 For a cross analysis, F. Giovanella, Copyright and Information Privacy. Conflicting Rights in Balance (Cheltenham: Edward Elgar, 2017).

3 K. Zale, 'Sharing Property' University of Chicago Law Review (2016) 87, 501-579.

4 R. Schulze and D. Staudenmayer (eds), Digital Revolution: Challenges for Contract Law in Practice (Baden-Baden: Nomos - Hart, 2016); A. De Franceschi, 'European Contract Law and the Digital Single Market. Current Issues and New Perspectives', in A. De Franceschi (ed), European Contract Law and the Digital Single Market (Cambridge: Intersentia, 2016) 1-17; S. Grundmann and P. Hacker, 'The Digital Dimension as a Challenge to European Contract Law - The Architecture', in S. Grundmann (ed), European Contract Law in the Digital Age (Cambridge: Intersentia, 2018) 3-45. 
lines anticipated well before the digital revolution. ${ }^{5}$ The concept of contract parties shades in the role of tens of different intermediaries providing information, opinions or services, all instrumental to e-purchasing. ${ }^{6}$ The net of liabilities underlying these roles is hard to reconcile with traditional concepts of privity of contract. ${ }^{7}$ The idea of exchange contracts is radically changed once money is no longer the only and main instrument for purchasing goods and services. ${ }^{8}$ Even unjust enrichment and restitution need new parameters to strike their balance.

How is private law adjusting its rules and principles to similar tensions? By creating a new body of norms or by adapting existing ones? What is the role of EU law in this process?

The present article will address these issues having special regard to the field of contract law and the changes brought by the rise of new trading models linked with online platforms and marketplaces. It will specifically examine some of the new EU initiatives in the field of digital contract law, questioning whether they provide sufficient regulatory answers to the challenges brought by the digital revolution and how existing gaps can be filled further.

More particularly, the article focuses on two main policy issues: (i) whether EU legislation should go beyond the adaptation of existing rules by opting for a sharper turn towards dedicated regulatory tools in the field of digital law, and (ii) whether the digital dimension of trade should lead to revisions of the current focus on consumer protection and, more broadly, the current divide between 'business-to-consumer' (hereinafter BtoC) and 'business-to-business' (hereinafter BtoB) law. After introducing the most recent trends in digital trade and internal market regulation, Section II shows the positioning of EU current initiatives along the lines of the possible regulatory options underlying the posed questions. In Section III, three areas are selected in order to exemplify the approaches taken by EU law in respect of the above regulatory options, their shortcomings and possible development perspectives: platforms' use of unfair terms and practices (III.1),

5 R. Brownsword et al (eds), Contract and Regulation. A Handbook on New Methods of Law Making in Private Law (Cheltenham: Edward Elgar, 2017); Grundmann and Hacker, n 4 above, 3-45.

6 U. Gasser and W. Schulz, Governance of Online Intermediaries: Observations from a Series of National Case Studies. Berkman Center Research Publication No 2015-5. Available at SSRN: https://s srn.com/abstract=2566364 or http://dx.doi.org/10.2139/ssrn.2566364.

7 C. Mitchell, 'Network commercial relationships: what role for contract law?', in Brownsword et al (eds), $\mathrm{n} 5$ above, 198 et seq.

8 Grundmann and Hacker, $\mathrm{n} 4$ above, 10. Cf also eg C. Langhanke and M. Schmidt-Kessel, 'Consumer data as consideration' Journal of European Consumer and Market Law 2015, 218 et seq; J. Sénéchal, 'The Diversity of the Services provided by Online Platforms and the Specificity of the Counter-performance of these Services-A double Challenge for European and National Contract Law' Journal of European Consumer and Market Law 2016, 39 et seq. 
transparency of ranking and users' review tools (III.2), platforms' liability for violations related with underlying supply contract (III.3). Section IV presents the main conclusions developed in previous sections.

\section{A Digital Internal Market: some Regulatory Options from a EU Perspective}

Recent surveys have shown the impact of digital revolution on economy and society and, more particularly, the role played by online platforms in this respect. Not only has digital trade grown enormously but it has enabled both traders and consumers to access markets they would have never reached. Crossborder trading has become cheaper; new businesses, including SMEs, have emerged; choice of goods and services has radically enlarged; niche products have become available; new job opportunities have emerged. ${ }^{9}$ The potentials for the EU internal market have been pointed to by analysts and policy makers, although all are aware that in this respect Europe runs behind North America and Asia. ${ }^{10}$

Growth opportunities do not come without challenges, though. Some of these require policy answers at global, regional or national level. EU institutions have developed a Digital Single Market Strategy for Europe in 2015, built on three pillars; whereas the second and the third pillars relate to infrastructures, technologies and content services, the first one envisions actions needed to ensure better access for consumers and businesses to online goods and services across Europe through the removal of barriers to cross-border online activity. ${ }^{11}$ In this respect, particularly relevant from a European Private Law perspective, the Commission has envisioned a process of simplification and 'modernisation' of rules for online and digital cross-border purchases through the harmonisation of the main rights

9 M.H. Thelle et al, 'Online Intermediaries: Impact on the EU Economy' EDiMA, October 2015, available at https://www.copenhageneconomics.com/publications/publication/online-intermedi aries-impact-on-the-eu-economy; European Commission, 'A Digital Single Market Strategy for Europe' $\operatorname{COM(2015)} 192$ final, 11; European Commission, 'A comprehensive approach to stimulating cross-border e-Commerce for Europe's citizens and businesses' COM(2016) 320 final, 2; European Commission, 'Online Platforms' SWD(2016) 172 final, 11 et seq. See also European Commission, 'Impact Assessment accompanying the Proposal for a Regulation on promoting fairness and transparency for business users of online intermediation services' $\operatorname{SWD}(2018) 138$ final, 59 et seq. 10 European Commission, n 9 above, SWD(2016) 172 final, 11 et seq; UNCTAD, n 1 above, 78. 11 European Commission, n 9 above, COM(2015) 192 final. 
and obligations of the parties to a contract of sale. ${ }^{12}$ Within the same perspective, the recent action taken by the European Commission for the reform of certain consumer directives (namely those on unfair terms, price indications, unfair commercial practices and consumer rights, hereinafter UCTD, PID, UCPD, CRD, respectively) can be explained, at least in part, as an attempt to modernise the existing rules in line with developments in the digital sphere. ${ }^{13}$ Moreover, a need has been addressed for more rapid, agile and consistent enforcement of consumer rules for online and digital purchases to make them fully effective: the recent reform of the EU Regulation on Consumer Protection Cooperation (hereinafter, CPCR) has specifically addressed this need. ${ }^{14}$

If all the above initiatives look at the impact of digitalisation of trade on the demand side (particularly from the consumers' perspective), other challenges emerge on the supply side, differently concerning the offer and supply of goods and services through the internet and the supply of online intermediation services within marketplaces, search engine applications, social media. Under this respect recent policy initiatives build on the approach taken by the so called E-Commerce Directive 2000/31/EC. At that time, the main purpose was indeed to create a legal framework to ensure the free movement of information society services across Member States and to remove legal obstacles, arising from uncertainty and divergences in legislation, to the proper functioning of the internal market. ${ }^{15}$ The liability exemption for hosting service providers in respect of information stored is consistent with the objective of ensuring free movement of services without imposing any active monitoring duty over possibly illegal contents and related activities over the internet, unless the provider has obtained actual knowledge or awareness. ${ }^{16}$

12 Proposal for a Directive amending Council Directive 93/13/EEC, Directive 98/6/EC, Directive 2005/29/EC and Directive 2011/83/EU as regards better enforcement and modernisation of EU consumer protection rules, $\operatorname{COM}(2018) 185$ final.

13 See COM(2018) 185 final, 1. For a critical view: M.B.M. Loos, 'The Modernization of European Consumer Law: A Pig in a Poke?' European Review of Private Law 2019, 113-134.

14 Regulation (EU) 2017/2394, Recital 14.

15 Directive 2000/31/EC Directive, recitals 8 and 5. See A. R. Lodder, European Union E-Commerce Directive - Article by Article Comments (2007). Guide to European Union Law on E-Commerce, 4 (Elgar Commentaries series, 2017) 15 et seq, 29 et seq. For a critical view: P. Tereszkiewicz, 'Digital Platforms: Regulation and Liability in the EU Law' European Review of Private Law 2019, 903-920, 904 et seq.

16 See C. Cauffman, 'The Commission's European Agenda for the Collaborative Economy - (Too) Platform and Service Provider Friendly?' Journal of European Consumer and Market Law 2016, 238; A. De Franceschi, 'Uber Spain and the "Identity Crisis” of Online Platforms' Journal of European Consumer and Market Law 2018, 1 et seq. 
In the present context, although free movement of information society services is ensured, barriers still exist opposing to the proper functioning of the internal market: not only on the demand side, as seen above, in respect of rules applicable to online purchases and for an effective enforcement when purchasers' rights are violated across the Internet; but also on the supply side, where the enormous growth of online intermediation service providers has created new imbalances between a limited number of big operators and a high number of small merchants selling their goods and services through those platforms. ${ }^{17}$ While these imbalances are relevant from the competition law perspective, ${ }^{18}$ they also hamper the proper functioning of the internal market from the perspective of trading transactions within supply chains. Indeed, they have an impact on the ability of small businesses to profitably access and compete in the market and on the consumers' capacity to exploit the benefits of online trade. ${ }^{19}$ Tackling these shortcomings of the EU digital markets is among the objectives of the EU/2019/1150 Regulation on promoting fairness and transparency for business users of online intermediation services (hereinafter OIS). ${ }^{20}$

To what extent do these legislative initiatives provide sufficient answers to the challenges brought by the use of digital technology in business and consumer trade? Would a stronger turn towards digital private law have been preferable? Is the BtoC/BtoB divide still the best tool to draw the new legal infrastructure for online trade?

\section{II.1 Digital Private Law: Adaptation of existing Regulatory Instruments or Adoption of Dedicated Ones?}

In abstract terms, three options would be available to address the legal issues posed by the digital revolution in the realm of contract law: (i) a generalist approach, suggesting that new challenges may be tackled through (existing or new) instruments equally applicable to offline and online trade; (ii) an adaptive ap-

17 See European Commission, Study ENTR/04/69, Legal Study on unfair commercial practices within B2B e-markets, Final Report, May 2006.

18 See OECD (2018) 'Rethinking Antitrust Tools for Multi-Sided Platforms' (www.oecd.org/competition/rethinking-antitrust-tools-for-multi-sided-platforms.htm).

19 See European Commission, n 9 above, SWD(2018) 138 final, 23, 31 et seq.

20 See Proposal for a Regulation on promoting fairness and transparency for business users of online intermediation services, $\operatorname{COM}(2018) 238$ final. For a comment, C. Busch, 'Towards Fairness and Transparency in the Platform Economy? A First Look at the P2B Regulation', in A. De Franceschi and R. Schulze, Digital Revolution - New Challenges for Law (Munich - Baden-Baden: CHBeck - Nomos, 2019) 57 et seq. 
proach, leading to adapt existing regulatory instruments to the specificity of new communication systems when needed; (iii) a dedicated approach, opting for the adoption of ad hoc regulation in this field..$^{21}$ The relevance of the three regulatory approaches in the EU landscape is very different, the second option being still the preferred one.

Indeed, the ad hoc approach under (iii) is gradually gaining attention in some of the Member States. ${ }^{22}$ By contrast, at the EU level, though somehow introduced with the E-Commerce directive, it currently remains a minoritarian option, now re-launched by the EU/2019/1150 Regulation on online intermediation services. Although still limited to platforms targeting consumers, this initiative paves the way towards a possible expansion of EU instruments in the field of digital law, including BtoB relations in the regulatory space.

In almost all the other initiatives, the observed attention paid by EU institutions to consumer protection has led policy makers to prioritize the adaptive approach over the others in order to 'modernise' consumer law through adaptations of existing legislation. Already the Consumer Right Directive has been partly inspired by the growth of distance selling on the internet. The most recent intervention, known as New Deal for Consumers, is also leading to important modifications of existing consumer directives (including the UCPD and the CRD) linked with the specificities of e-commerce and so called online marketplaces. ${ }^{23}$

More debated has been the scope of EU intervention in the area of sale of goods, probably the core of the envisioned modernisation process. After a longlasting debate at both political and academic levels, the recently adopted directives endorse the option of a dedicated tool in respect of the supply of digital contents, whereas they move away from this option when it comes to the online sale legislation. Indeed, in the latter case, following a more generalist approach, as described above under (i), the new consumer sales directive (EU/2019/771) covers both offline and online sales without providing any specific rule for online platforms.

21 These distinctions may only partially be compared with the one illustrated by C. Twigg-Flesner, 'The EU's Proposals for Regulating B2B Relationships on online platforms - Transparency, Fairness and Beyond' Journal of European Consumer and Market Law 2018, 222-233, between 'coherentism' and 'regulatory instrumentalism' (drawn on Brownsword's and Rubin's works).

22 See, for France, Loi pour une République numérique of 7 October 2016; see, for other references European Commission, n 9 above, SWD(2018) 138 final, Annexes, 92. See J. Sénéchal, 'French Law on Online Platforms and Discussion Draft of a Directive on Online Intermediary Platform: Common or Divergent Approaches?', in C. Busch et al (eds), Discussion Draft of a Directive on Online Intermediary Platforms. Commentary (Krakow: JUP, 2019) 235 et seq.

23 See sec III below. 
The need to have coherent rules for distance and face-to-face sales has prevailed, without leaving substantive space for an express adaptation of the rules when applied to online trade. In the light of the results of a recent monitoring process launched by the European Commission, the need for more harmonised rules in this area has been particularly linked with the growth of multichannel business models, combining both online and offline trade. In the EU legislator's view, exposing these businesses to a dual system (one based on minimum harmonization and another one, more preferably, on full harmonization) would worsen the current fragmentation of consumer sales law across EU Member States. ${ }^{24}$ Why this is not compatible with a sub-set of rules on sale through online platforms, has not been clarified, though, and deserves further attention. ${ }^{25}$ More particularly, regulatory answers would have been needed to clarify whether or in which circumstances platforms may bear any (direct or joint) responsibility for lack of conformity of goods and whether or in which circumstances immediate termination may be sought in online contracts. ${ }^{26}$ Section III. 3 will specifically address these aspects.

The choice among the three regulatory options above described depends on both the objectives pursued and the status of current rules with special regard to their aptness to address the legal issues posed by the digital turn. In Section III, some of these challenges will be examined taking into consideration the new EU initiatives following either the adaptive or the dedicated approach. Both solutions will show their potentials, somehow confirming that, compared with them, a generalist approach would not represent a better option in their field of application. While digital trade law is still a recent area of intervention at MS level, it seems that the objective of ensuring a better functioning of internal market would be better pursued by not simply adapting current consumer protection law but taking a stronger approach towards ad hoc tools, able to more systematically address typical failures of digital trade markets. ${ }^{27}$ More particularly, the analysis below will help us to understand why dedicated legislation is needed to tackle the lack of transparency and unfairness of terms and practices engaged by online platforms well beyond

24 European Commission, 'Report of the Fitness Check' SWD(2017) 209 final, 62 et seq.

25 Loos, $n 13$ above, 134.

26 See on this point sec III below. Equivalent issues would regard the case of lack of delivery addressed in the Consumer Right Directive. Both the Consumer Right Directive and the current proposal for reform of the Consumer Sale of Goods Directive admit immediate termination among available remedies under special circumstances, without opening any other allowance for online sales. 27 See De Franceschi, n 4 above, 17; R. Brownsword, 'The E-Commerce Directive, Consumer Transactions, and the Digital Single Market - Question of Regulatory Fitness, Regulatory Disconnection and Rule Redirection', in Grundmann (ed), n 4 above, 165-204. 
the instances covered by current legislation (Sections III.1 and III.2). It will also emerge that the adaptive approach, only partially endorsed by the New Deal for Consumers, may prove very useful to take into account digital specificities in the current system of consumer protection with special regard to platforms' liability for violations occurred within online transactions.

\section{II.2 Digital Markets and the BtoB/BtoC Divide: towards new Perspectives}

Primarily driven by the need for the establishment and well-functioning of internal market, EU law has largely focused on consumer law as a response to market failures. ${ }^{28}$ More rarely these failures have called for EU action in the area of BtoB law, although more recent initiatives are populating this important field. ${ }^{29}$ As a consequence, looking at the core of EU contract law, online transactions 'mediated' by platforms could fall within the scope of current EU legislation only to the extent that purchasers may qualify as consumers and suppliers as businesses, whereas transactions engaged by business purchasers or non-professional suppliers would remain out of this scope. ${ }^{30}$

The mandate for a high level of consumer protection imposed by the Treaty and the Charter upon EU policies has also inspired the E-Commerce Directive as well as the 'Digital Single Market Strategy'. Indeed, despite its more general scope of application, the E-Commerce Directive does ensure a special level of consumer protection, mainly by means of rules that can be opted out only between parties

28 R. Schulze and F. Zoll, European Contract Law ( $2^{\text {nd }}$ ed, Baden-Baden: Nomos; Munich: CHBeck; Oxford: Hart Publishing, 2018) 1 et seq, 5 et seq; H. Beale et al, Cases, Materials and Text on Contract Law ( $3^{\text {rd }}$ ed, Oxford: Hart Publishing, 2019) 35.

29 Besides the OIS Regulation, see Directive (EU)2019/633 on unfair trading practices in businessto-business relationships in the agricultural and food supply chain. See J. Stuyck, 'The Unfair Commercial Practices Directive and its Consequences for the Regulation of Sales Promotion and the Law of Unfair Competition', in S. Weatherill and U. Bernitz (eds), The regulation of unfair commercial practices under EC directive 2005/29: new rules and new techniques (Oxford, Portland: Hart, 2007) 159 et seq. For a comparative view on the BtoB and BtoC legal frameworks on unfair practices, P. Iamiceli, 'Unfair Practices in Business-to-Consumer and Business-to-Business Contracts: A Private Enforcement Perspective' (2016) Revista da Faculdade de Direito da UFMG 335. Much more discussed is whether that lens should also push EU legislation into the CtoC relation area. See European Commission, $\mathrm{n} 24$ above, SWD(2017) 209 final, 70.

30 European Commission, A European agenda for the collaborative economy $\{\operatorname{SWD}(2016) 184$ final\}, $\operatorname{COM(2016)~} 356$ final, 9; Cauffman, n 16 above. On the distinction between professional and non-professional online traders see CJEU, 4 October 2018, Case C 105/17, Komisia za zashtita na potrebitelite v Kamenova. 
who are not consumers, being mandatory in the BtoC context. ${ }^{31}$ Even more focused on consumer protection are most of the initiatives proposed under the Digital Market Agenda in the fields of commercial practices, consumer rights and protection cooperation.

Partially new is the approach taken in the EU/2019/1150 Regulation on OIS providers. Indeed, in this case, the digital lens pushes EU legislation up to the chain of trade within the domain of BtoB relations. To be clear, this Regulation does not address all BtoB relations established in a digital environment, but only the supply relations through which businesses supply goods or services through platforms targeting consumers (BtoPtoC). ${ }^{32}$ Supplies by non-professional providers are excluded as well as supplies through platforms exclusively targeting businesses (PtoB).

The approach taken is based on the neutrality of the digital dimension in respect of the distinction between $\mathrm{BtoC}$ and $\mathrm{BtoB}$ relations, so that the same taxonomy is replicated in this different environment without major differences. In fact, this neutrality is deeply challenged by the concrete functioning of digital markets. ${ }^{33}$ Not only is the personal or professional purpose of supplies and purchases hardly observable over the internet, but also some of the market failures hampering digital trade seem to affect almost equally professionals and consumers, leading us to question the exclusivity of consumer protection; indeed, these failures are related to the means of communication and the lack of direct control over the transaction more than on the information or market options held by economic players.

Section III will help to understand some of the shortcomings of the narrow approach taken by current legislation. The analysis will show that, while some level of transparency and fairness should be ensured for the benefit of any platform users, these being professional or not, regulatory initiatives focused on consumer protection in digital markets should not be discouraged. This is applicable in particular when digital technology exacerbates the informational and cognitive weaknesses normally affecting consumers (Sections III.1 and III.2). Moreover, the different role played by platforms in BtoB and BtoC markets may suggest a diversification of monitoring duties and liability rules (Section III.3).

31 See, particularly, art 10 and 11, E- Commerce Directive. See Lodder, n 15 above, 25.

32 Busch, $\mathrm{n} 20$ above, 57.

33 Cauffman, n 16 above, 238; European Commission, n 30 above, 9. 


\section{Testing the Hypotheses through the Lens of current Legislative Initiatives}

In the analysis below, both the hypotheses above presented will be tested: (i) the one concerning the need for ad hoc regulatory tools on online trade as a prior or complementary option in respect of adapting existing legislation to the digital turn and (ii) the one concerning the need for reconsideration of the classical divide between $\mathrm{BtoC}$ and $\mathrm{BtoB}$ relations in digital trade law.

These hypotheses will be examined having regard to regulatory answers provided by current initiatives in the following areas: unfair terms and unfair practices (section III.1), ranking and users' review tools (section III.2), liability for violations related with underlying contractual relations mediated by the platform (section III.3). Section IV will conclude the analysis.

\section{III.1 Online Platforms make Markets thicker... though unbalanced: regulating the Use of Unfair Terms and Unfair Trading Practices by Online Platforms}

Recent studies show that the growth of digital trade enables the emergence of new businesses and new business models. It also facilitates the access of small and medium businesses to new market and distribution channels, which in turn eases their growth. In a nutshell, digital technologies seem to make markets 'thicker' with beneficial effects in terms of competitiveness at both EU and global level. ${ }^{34}$

Other factors challenge this process, however. Online platforms are in fact controlled by few giant players. ${ }^{35}$ By exploiting digital technology creating 'places' for easy matching of demand and offers of goods and services among huge groups of users, these players are able to benefit from the typical network effects linked with (offline and online) platforms. ${ }^{36}$ Operating as 'multi-sided markets', online platforms derive unprecedented comparative advantages from their control over an enormous amount of data concerning users' preferences and habits in very different respects of their life. ${ }^{37}$ This comparative advantage leads to

34 Thelle et al, $\mathrm{n} 9$ above.

35 European Commission, n 9 above, SWD(2018) 138 final, 9, 16 et seq.

36 By network effects it is commonly intended that the value of the network increases with the number of participants (see European Commission, n 9 above, SWD(2016) 172 final, 4).

37 B. Martens, 'An Economic Policy Perspective on Online Platforms', IPTSDE Working Paper 2016/05, JRC101501. 
remarkable asymmetries and creates the space for possible unfair practices harming not only consumers but also business users. ${ }^{38}$ Such a risk becomes more substantial the higher the growth of digital trade; over time, this growth makes business users 'dependent' upon online platforms. ${ }^{39}$ The exercise of 'regulatory powers' through the definition of privacy policies, terms of services and other general terms reinforces these asymmetries calling for new regulatory answers. ${ }^{40}$

In the view of the European Commission, these risks lower the trust of business users in digital economy with a huge impact on the functioning of internal market. Together with the consequences of regulatory fragmentation linked with upcoming and non-coordinated initiatives at national level, these effects make clear the need for a regulatory response by EU institutions under the coverage of Article 114 TFEU. This regulatory response is therefore mainly aimed at increasing the transparency of online platforms and reducing the risk of unfair practices in BtoP relations.

Moving from this perspective, the EU/2019/1150 Regulation tackles both unfair terms and unfair practices but, unlike in consumer law, a full list of target terms and practices is not annexed. ${ }^{41}$ Moreover, as regards unfair practices, a general prohibition is lacking. ${ }^{42}$ Instead, the focus is on few major types of unfairness, namely those concerning unilateral or retroactive changes of terms and conditions; restriction, suspension and termination of the service provisions; the determination of ranking parameters; differentiated treatments in respect of intermediation services concerning goods or services offered by the platform itself. Fairness is mostly conceived as procedural: practices are not simply prohibited; rather, they are enabled to the extent that compliance is ensured with information duties, notice requirements, statements of reasons, parameters determining busi-

38 European Commission, Study on contractual relationships between online platforms and their professional users, FWC JUST/2015/PR/01/0003/Lot1-02, Final Report (Luxembourg: Publications Office of the European Union, 2018); Martens, n 37 above, 4; Grundmann and Hacker, n 4 above, 19. 39 See European Commission, n 9 above, SWD(2018) 138 final, 23. This type of 'dependency' is rather different from the one linked to other forms of unfair practices in offline market, where economic dependence is mostly related with the shortage of alternative options for trade in the market and(or) the type of investments made by the dependent firm, not being re-employable in alternative transactions.

40 D. Wielsch, 'Private Law Regulation of Digital Intermediaries' European Review of Private Law 2019, 197-220.

41 See, however, art 8 OIS Regulation, on specific contractual terms 'ensuring that contractual relations are conducted in good faith and based on fair dealing', in fact providing a short list (three items) of fair terms and practices.

42 See, however, art 1 OIS Regulation, defining the purpose of the legislation in terms of granting 'appropriate transparency, fairness and effective redress possibilities' to business users of OIS. 
ness choices, etc. ${ }^{43}$ Specific information duties are also prescribed with regard to access to data by both the intermediation service provider and the business users. $^{44}$

\section{III.1.1 The Use of Unfair Terms and Unfair Practices by Online Platforms: the Need for ad hoc Legislation}

By first examining a number of regulatory options, the Commission has concluded that a dedicated legislative initiative on transparency and fairness of online intermediation service providers was needed. ${ }^{45}$

By contrast, the option consisting in adapting existing legislation has been discarded. Like in other sectors, eg agrifood, the sufficiency of competition law has been excluded since many of the feared practices would fall outside of the scope of application of this field of law. ${ }^{46}$ Yet, competition law, unfair competition law and other legislation, established also at national level to tackle unfair trading practices, would continue to play a complementary role. ${ }^{47}$ Neither consumer law, namely the UCTD and the UCPD, as extended or adapted to BtoP relations, would provide an effective and proportionate regulatory answer: not effective, since specific aspects of platform transactions would remain unaddressed; disproportionate, because, in the view of the Commission, only supplies through platforms targeting consumers should be addressed and not any type of BtoP relations.

43 This approach may be compared with the one taken in EU/2019/633 Directive on unfair trading practices in business-to-business relationships in the agri-food supply chain, providing both a black and a grey list of practices. See F. Cafaggi and P. Iamiceli, 'Unfair Trading Practices in food supply chains. Regulatory responses and institutional alternatives in the light of the new EU Directive', European Review of Private Law (2019) 1075-1114.

44 For a comment on the main provisions of the Regulation, as conceived in the original proposal: Twigg-Flesner, $\mathrm{n} 21$ above, 225.

45 More precisely, the preferred option has been the co-regulatory one, combining legislation with private regulation, whereas a purely private regulatory approach has been discarded (European Commission, $\mathrm{n} 9$ above, SWD(2018) 138 final, 40 et seq). This conclusion has been reached by looking at the private regulatory experience in agri-food sector (see Cafaggi and Iamiceli, $\mathrm{n} 43$ above).

46 See European Commission, 'Initiative to improve the food supply chain (unfair trading practices) accompanying the document Proposal for a Directive on unfair trading practices in businessto-business relationships in the food supply chain' SWD(2018) 92 final, 35.

47 European Commission, n 9 above, SWD(2018) 138 final; art 1(4)(5) OIS Regulation. See also Grundmann and Hacker, $\mathrm{n} 4$ above, 23. 
More particularly, current consumer-based legislation would fail to address types of unfairness which are mostly linked with the operation of online platforms as intermediaries able to affect access to market and value allocation along the chain: ${ }^{48}$ in online marketplaces, eg, the use of restrictions, suspension or termination of services becomes of primary importance, calling for dedicated regulation; so also for the rules on access to data or use of ranking. For example, comparing the rules on contract termination by OIS (Article 3(1)(c) and Article 4, OIS Regulation) and the ones on termination clauses in consumer contracts (Article 3(3), Annex, $1(\mathrm{~g})$, UCTD), one could observe the former being in general stricter than the latter: grounds for termination need to be explicitly set out by online platforms; normally, a notice period is not an alternative but is cumulative in respect of the statement of reasons; contract terms contrary to these requirements are null and void as such, not only presumably unfair and therefore ineffective. Indeed, unfairly terminating an OIS contract may largely affect suppliers' access to market, being often the search for alternative options much more costly for a (small) supplier offering goods or services online than for a consumer buying online or offline.

Moving from BtoC to BtoB existing legislation, regulatory answers are not easily available either. For example, even regardless of their limited scope of application sector-wise, the recently adopted rules on unfair trading practices in agri-food supply contracts would be hardly adapted to the different context of BtoP relations. ${ }^{49}$ This consideration applies, eg, to the severe rules totally banning practices such as unilateral changes in agri-food contract terms (Article 3.1(a)(c), EU/2019/633 Directive): abrupt changes may in fact generate severe consequences upon food suppliers but they may determine more limited effects for the online market in other sectors, if, despite the role of platforms, suppliers are still able to adapt to the requested changes and access the retail market through alternative channels. Therefore, a more flexible rule has been preferred. ${ }^{50}$

48 Twigg-Flesner, $\mathrm{n} 21$ above, 226. For a sharper distinction between off-line and online contract legislation also within consumer protection, Brownsword, n 27 above, 171 et seq. Along similar lines, again for a reinforced transparency in online consumer contracting, R. Momberg, 'Standard Terms and Transparency in Online Contracts', in De Franceschi (ed), n 4 above, 189-207.

49 Although some extensions could improve legislation on online platforms, eg with regard to the unfair imposition of unjustified fees on suppliers.

50 Under the OIS Regulation, unilateral changes are not strictly prohibited; they are subject to a notice period and a supplier's right of termination within the same period (art 3(2), OIR Reg). On the relation between power and value allocation along the chain and its consideration in the recent directive on unfair trading practices in the food sector, see Cafaggi and Iamiceli, $\mathrm{n} 43$ above, underlying the relevance of so called 'systemic effects' stemming from unfairness along the food supply 
The core ratio of the new Regulation stands in the 'intermediation' role of the platform and its distinctive ability to govern power and value allocation in the online market well beyond the 'neutrality assumption' underlying the E-Commerce Directive. ${ }^{51}$ Contract terms and contractual practices are both instruments used by platforms to increase efficiency in mass trade (eg, by lowering transactions costs through standardization of terms and conditions or through negotiation of collateral services such as payment, delivery, etc) and to exploit network advantages linked with the use of technology in multi-sided markets. Unfair terms and unfair practices allow platforms to shift costs and risks to weaker parties, mostly small suppliers, so undermining their competitive capacity. Opting for a dedicated legislative instrument, like the OIS Regulation, has allowed to define fairness standards for both terms and practices taking the platforms' role and related risks into account. ${ }^{52}$

\section{III.1.2 The BtoC/BtoB Divide: Power Unbalances and the Status of the Contract Parties}

Under Article 1, the OIS Regulation only applies to online intermediation services and online search engines provided, or offered to be provided, to business users and corporate website users, respectively, that, through those platforms, offer goods or services to consumers. Not only does this limitation raise concerns on the 'customer side' in respect to the exclusion of platforms targeting business purchasers. It also creates ambiguity on the 'supply side' with special regard to the notion of 'business user'.

Indeed, business users are conceived as professional users acting for purposes relating to their trade, business, craft, profession. The nuances of the so called 'collaborative economy', providing access to new forms of exchanges between non-professional users, are therefore kept aside, although the latter are exposed to similar or higher risks of unfairness in their relation with the platform. ${ }^{53}$ As a consequence, whereas in preparatory documents, platforms like Uber and Airbnb have been fully considered within the scope of this initiative, one

chain. For a first comparison between the two initiatives: C. Twigg-Flesner, 'Towards a European law on unfair B2B trading practices?' Journal of European Consumer and Market Law 2018, 93.

51 See UNCTAD, $\mathrm{n} 1$ above, 79. For more critical implications, see sec III.1.3 below.

52 On the preference of a regulatory approach focused on the role of platforms as 'market makers', Twigg-Flesner, $\mathrm{n} 21$ above, 332.

53 See European Commission, Guidance on the implementation/application of Directive 2005/29/ EC on unfair commercial practices, $\operatorname{SWD}(2016) 163$ final, 30, and the criteria therein defined to 
should conclude that only professional drivers or hosts, if ever contracting through Uber or Airbnb, could benefit from the application of the new Regulation. ${ }^{54}$

Which rules would then be applicable to contracts between non-professional suppliers and the platform? Which rules could address, eg unfair suspension or termination of these relations? The applicability of consumer law has been questioned with regard to so called CtoB relations; even more so, in this context, has been the applicability of the UCPD, if ever useful as such in the outlined circumstances..$^{55}$ By contrast, the relation between a non-professional user and a platform, although somehow escaping from the $\mathrm{BtoC} / \mathrm{BtoC}$ divide, does deserve some attention through the lens of unbalanced relations used by EU law within the scope of Article 114 TFEU.

As observed in a recent case discussed on social networks before the Court of Justice, the line between professional and social life blurs against the 'fifty shades' of colours identifying online communities established in the internet (including marketplaces). ${ }^{56}$ The question whether the gaps left by these shades should be filled in within the boundaries of consumer protection, along the lines of the New Deal for Consumers, or within a more comprehensive legislation on online platforms, surely deserves further attention. ${ }^{57}$

Especially in the latter perspective, which may be preferable, the BtoC/BtoB divide has to be aligned with the notes (or shades) of digital marketplaces and eventually fade into different divides. For example, fairness regulation could be extended to all supply relations in which the platform retains a certain control in terms of providers' access to market, eg having power to suspend or terminate the provision of intermediation services, to affect the ranking of users' offer on the platform, to determine prices or other key terms of the supply contract. ${ }^{58}$ Rever-

establish whether providers in online platforms are traders or not. See V. Hatzopoulos, The Collaborative Economy and EU Law (Oxford: Hart Publishing, 2018) part ch 1 and 2.

54 See European Commission, n 9 above, SWD(2018) 138 final, Annex, 15, specifying that, after the Uber judgment, that model of platform addressed by the Court should be excluded from the Regulation's scope of application. For a critical view on this approach see F. Maultzsch, 'Contractual Liability of Online Platform Operators: European Proposals and established Principles' European Review of Contract Law 2018, 209-240, 221.

55 See European Commission, n 24 above, SWD(2017) 209 final, 71, where no reference is done however to online platforms.

56 Opinion of AG Bobek, 14 November 2017, C-498/16, M. Schrems v Facebook Ireland, 46, 48.

57 See C. Twigg-Flesner, 'Bad Hand? The "New Deal” for EU Consumers' Zeitschrift für das Privatrecht der Eruopäischen Union (GPR) 2018, 166 et seq. On the regulatory lacks on unfair commercial practices in BtoB platforms see already European Commission, n 17 above, Study ENTR/04/69.

58 On possible implications of platform control upon liability, see below sec III.3. 
sing the 'neutrality assumption' underlying the conventional interpretation of the E-Commerce directive, the exercise of power over 'mediated' transactions does not extinguish the intermediary role of platforms but requires specific answers to unfairness.

Interestingly, the regulatory and control power of platforms over suppliers has been referred to as a criterion to assess whether a service provided by electronic means is separable from other services having material content; this separation would prevent the classification of being an 'information society service' (ISS), which is a prerequisite for the application of both the E-commerce directive and the OIS Regulation. With regard to the E-commerce directive, this analysis has led the Court of Justice to exclude the possibility that UberPop could qualify as ISS provider ${ }^{59}$ and the Advocate General Szpunar to take a different view on Airbnb, that has been therefore recognized as an online intermediary. ${ }^{60}$ In the first case the Court has made clear that the classification is lost when: (1) outside the platform neither the provider would offer goods/services, nor the customer would purchase them from that provider and (2) the platform exercises a direct influence over the terms and conditions of the contract with the final customer and a certain control on the quality of the services provided and suppliers, which can, in some circumstances, result in their exclusion. ${ }^{61}$ Regulatory, monitoring and exclusionary powers matter. ${ }^{62}$ What for?

The 'Uber test' has been developed in order to limit the application of the special regime designed by the E-commerce directive to online intermediaries whose business model is entirely digital. The same definition of ISS provider has been used in EU/2019/1150 Regulation, however, without considering all the implications deriving from the 'Uber test' when applied to legislation with different

59 See CJEU, 20 December 2017, Case C 434/15, Asociación Profesional Élite Taxi v Uber Systems Spain SL, para 40. See P. Hacker, 'UberPop, UberBlack, and the Regulation of Digital Platforms after the Asociación Profesional Elite Taxi Judgment of the CJEU' European Review of Contract Law 2018, 80-96. See also CJEU, 18 April 2018, Case C-320/16, Uber France v Nabil Bensalem.

60 See Opinion of AG Szpunar, 30 April 2019, Case C 390/18, Airbnb Ireland UC: the AG holds that, unlike Uber, the Airbnb platform should be qualified as an ISS provider under the 2015/1535 Directive (referred to by the OIS Regulation to define OIS providers); however, being both professional and non-professional hosts part of the platform, the condition no 1 in the 'Uber test' would not hold (trade would exist out of the platform) and the accommodation services could not be held inseparably linked to the service provided by Airbnb Ireland by electronic means, therefore being unable to neutralize its role of information society service provider. For a different analysis, Hacker, n 58 above, 93.

61 CJEU, 20 December 2017, Case C 434/15, Asociación Profesional Élite Taxi v Uber Systems Spain SL, para 39 .

62 On the exclusionary effects of (unfair) trading practices see Cafaggi and Iamiceli, n 43 above. 
aims. Firstly, one could easily argue that, presumably, suppliers falling under condition (1) of this test are non-professional platform users (so for the Uber examined platform): consistently but still surprisingly, these would be excluded from the scope of application of the OIS Regulation. Secondly, under condition (2), rather than calling for legal protection, the intensity of platform's control over the material service provided by suppliers would push the platform away from the scope of application of a Regulation aimed at policing power unbalances between platforms and business suppliers. A totally different approach would have been expected from a regulation pursuing such objectives: that non-professional suppliers could equally benefit from regulated fairness and so for suppliers that, regardless their professional status, are subject to a platform's strong regulatory, monitoring and exclusionary power. Indeed, without setting aside the intermediary function of platforms, exercise of power calls for regulatory answers able to protect market players, whose economic activity may even evolve into more structured business models, so contributing to the development of the internal market. $^{63}$

\section{III.2 Online Platforms make more Information available: Information v Opinions and the Role of Ad hoc Transparency Regulation}

The use of internet and digital technology has definitively made enormous amount of information available for market players and end-purchasers. Behavioural economics explains the potential impact of this information on conduct and choice made by consumers and the rationality failures encouraged by these new modes of communication. ${ }^{64}$ Regulators and administrative enforcers are fully aware of this impact and interpret existing legislation, eg in the area of consumer protection, accordingly. ${ }^{65}$

63 Cf European Commission, n 30 above, 9.

64 See R. Calo, 'Digital Market Manipulation', George Washington Law Review (2014) 82, 995 1051; R. Calo and A. Rosenblat, 'The Taking Economy: Uber, Information and Power', Columbia Law Review (2017) 117, 1623-1690; A. Stemler, 'Feedback Loop Failure: Implications for the SelfRegulation of the Sharing Economy', Minnesota Journal of Law, Science \& Technology (2017) 18, 673-712. See also European Commission, Behavioural Study on the Transparency of Online Platforms: Final Report (2018).

65 See eg Tripadvisor decision by Italian Competition Authority (AGCM, 14 December 2014, PS 9345, no 25237). 
More information is not always preferable. When information is easily accessible, as is the case on the internet, two main issues arise: reliability on the one hand and comparability on the other. As regards reliability, not only may information sources be hardly verifiable over the internet, but also communication easily expands, creating an opaque mixture of information and opinions, where the latter tend to influence choices even more strongly than the former. Whereas information is not always scientifically driven or objectively verifiable, opinions carry by definition a subjective value that should always be made clear to recipients. In this and other regards, reliability of both information and opinions should be policed. Information may be derived from unreliable sources or been (intentionally or unintentionally) manipulated along the chain of internet accesses and transfers. The manipulation of opinions may be even easier to enact and more difficult to detect, making it harder for businesses to make credible commitments when managing user-review tools and for public authorities to monitor over their fairness. ${ }^{66}$

A peculiar and rather powerful instrument to channel information and opinions is 'ranking': not only search engines rank available options when listing links corresponding to the inserted query, but also online platforms do so when proposing a number of purchase options to internet users. One of the most critical aspects of ranking is exactly that it is not obvious whether ranking conveys information (ie the link proposed better suits the request made by the internet user on the basis of the query - keywords - submitted), opinions (ie the link proposed is the one that most users have accessed - maybe recurrently - when looking for similar goods or services) or neither (eg, the link directs to the trader who has obtained a higher ranking through added fees). ${ }^{67}$

The analysis below examines whether and to what extent ad hoc legislation would help police digital market transparency in this regard and in which respect the traditional divide between $\mathrm{BtoC}$ and $\mathrm{BtoB}$ relations can still offer a sufficient framework for the proper functioning of the digital market. The analysis will cover, first, ranking, then review tools.

66 See European Commission, n 64 above; C. Busch, 'Crowdsourcing Consumer Confidence. How to regulate Online Rating and Review Systems in the Collaborative Economy', in De Franceschi (ed), n 4 above, 223-243, 230; M. Narciso, 'The Regulation of Online Reviews in European Consumer Law' European Review of Private Law 2019, 557-582.

67 M. Cian, 'Online Platforms as Gatekeepers to the Digital World - A Preliminary Issue on Business Freedom, Competition and the Need for a Special Market Regulation' Journal of European Consumer and Market Law 2018, 209. 


\section{III.2.1 Ranking Goods or Services: how to combine PtoC and PtoB Transparency?}

Recent EU initiatives have been specifically concerned with ranking more than with user-review tools. ${ }^{68} \mathrm{~A}$ mixed regulatory approach has been taken, combining an adaptation of consumer law, with a dedicated set of rules on OIS transparency.

Due to the peculiar role of ranking within commercial practices, current consumer legislation would not ensure a sufficient level of transparency in this area. As a consequence, within the New Deal for consumers, a change is proposed in respect of the UCPD and the CRD with new information duties imposed on the side of traders allowing consumers to conclude online contracts. Indeed, as the proposal lays down, before a consumer is bound by a distance contract, or any corresponding offer, on an online marketplace, the online marketplace shall in addition provide the main parameters determining ranking of offers presented to the consumer as result of his search query on the online marketplace and their relative importance as opposed to other parameters. ${ }^{69}$

The recent OIS Regulation addresses the issue from the business perspective, so filling a different gap in the current legal framework. Information is due in the form of terms and conditions or standards established by OIS providers in their relations with business users. In the case of search engines, that information should be easily and publicly available on the online search engine itself, so expanding the benefits beyond the reach of the corporate website users. ${ }^{70}$ This information must include the parameters determining ranking and, more particularly, whether these parameters also concern: the characteristics of the goods and services offered to consumers through the online intermediation services or the online search engine; the relevance of those characteristics for those consumers; as regards online search engines, the design characteristics of the website used by corporate website users. If direct or indirect remuneration influences ranking, this should also be made clear to business users in their relation with online intermediation service providers (Article 5 OIS Regulation).

68 So for the OIS Regulation, exclusively dealing with ranking (see art 5). Latest amendments to the UCPD are, however, envisaged by the pending reform, covering consumer reviews besides ranking (see art 7(4a, 6), UCPD, and the integration of Annex I, in the proposal for reform approved by the European Parliament on 17 April 2019).

69 In addition to the reformed art 7(6), UCPD, cited, see also the amendment proposed in the same initiative in art 2(4), adding art 6 a to Directive 2011/83/EU (see lett $a$ ).

70 Consistently, art 7(4a), UCPD, as newly proposed, would not be applicable to search engines. On the possibility of framing the search engine 'services' in contractual terms, see P. Jacek Pałka, 'Terms of Services are not Contracts - Beyond Contract Law in the Regulation of Online Platforms', in Grundmann (ed), n 4 above, 135-161. European Commission, n 64 above. 
PtoC and PtoB transparency regulation addresses different market failures, calling for distinct regulatory answers. The former is triggered by the awareness of consumers' cognitive flaws in purchasing choices when influenced by ranking whose criteria are not specified. ${ }^{71}$ The latter aims at reducing the occurrence of more classical market failures, such as moral hazard and adverse selection, induced by information asymmetry between the platform and the supplier. ${ }^{72}$ Since the ranking specifically influences the value of the OIS for the supplier, transparency shall specifically concern criteria linked with the characteristics of goods and services offered through the platform and the relevance of such characteristics for the consumers.

In the PtoC context, regulating ranking transparency implies an adaptation and integration of consumer protection law, namely in the area of unfair commercial practices and information duties; in the BtoP one, absent a general legal framework on BtoB relationships, the adoption of a dedicated legal instrument is definitely needed. Due to the type of information asymmetry mentioned above, limiting its application to professional suppliers seems too a restrictive choice.

Though distinct, PtoC and BtoP rules should be jointly examined. The higher the transparency towards consumers, the more the choice of consumer-friendly criteria (eg product popularity) influences platforms' choices and, as a consequence, business preferences. By contrast, the disclosed influence of platforms' remuneration over ranking aims at reducing the risk of manipulation through suppliers' remuneration and at reinforcing consumer trust. Moreover, one of the most critical aspects of ranking is how the different criteria are reciprocally weighed and to what extent consumers may, totally or only partially, instruct ranking through their choice. The more complex the formula for ranking, the less observable and verifiable for businesses, consumers and monitoring authorities. Standards will probably flourish and private regulation may play an important role in setting a level playing field together with public regulation, along the lines drawn in Article 10 UCPD and Article 17(2) OIS. ${ }^{73}$

71 European Commission, n 64 above. See also M. Derakhshan, N. Golrezaei, V. Manshadi and V. Mirrokni, Product Ranking on Online Platforms (26 February 2018), available at SSRN: https://ss rn.com/abstract=3130378 or http://dx.doi.org/10.2139/ssrn.3130378.

72 A. Renda, F. Cafaggi and J. Pelkmans, Study on the Legal Framework Covering Business-to-Business Unfair Trading Practices in the Retail Supply Chain, Final Report, prepared for the European Commission, DG Internal Market DG MARKT/2012/049/E, February 2014, available at http://ec.eu ropa.eu/internal_market/retail/docs/140711-study-utp-legal-framework_en.pdf, 35, 122.

73 On the advantages of a co-regulatory approach, Busch, n 66 above, 230. 


\section{III.2.2 Transparency and User-Review Tools: modernizing Consumer Protection}

Unlike ranking methods, user-review tools have only been addressed in EU consumer protection initiatives, whereas no rule has been provided in the OIS regulation. If approved, the projected reform would reduce the gap left by current legislation with special regard to the exemption provided by the E-Commerce Directive. Indeed, the latter creates for platforms high incentives to remain passive in respect of false or unreliable reviews. ${ }^{74}$ The risk that this approach would permit a distorted use of reviews, thereby hampering the functioning of the internal market, is significant, in particular from the perspective of consumer protection.

Not surprisingly, a first regulatory proposal emerges in the area of unfair commercial practices. The provision proposed for the UCPD would oblige the trader to disclose whether and how it ensures that the published reviews originate from consumers who have purchased or used the reviewed goods or services and, when stating that reviews are submitted by consumers who have actually used or purchased the product, to take proportionate and reasonable steps in monitoring over it; consistently, traders' submission of false consumer reviews and misrepresentation of consumer reviews would be prohibited. ${ }^{75}$ It is important to highlight that a monitoring duty would explicitly emerge only in instances of clear statement about actual use or purchase by reviewing consumers. Moving from this consideration, the risk of platform passivism in respect of reviews would still be quite high.

An ELI Project is dealing with the definition of model rules on online platforms, specifically covering the use of reputation systems. ${ }^{76}$ Targeting different types of legislators, even beyond the EU boundaries, the Draft ELI Model Rules identify cases in which monitoring should be active (eg, again, when the platform claims that reviews are based on real transactions) or information should be given to platform users (eg if the review has been solicited in exchange for any benefit or if a reputation system excludes older reviews). They also address the critical issue concerning portability of reviews across platforms. ${ }^{77}$ Being part of a dedi-

74 For an in-depth analysis of the applicability to review tools of existing EU legislation on e-commerce and unfair commercial practices: Narciso, n 66 above, 566 et seq.

75 Art 7(6) and Annex I(23b), reformed UCPD.

76 For an introduction to the original draft proposal: Research group on the Law of Digital Services, 'Discussion Draft of a Directive on Online Intermediary Platforms' Journal of European Consumer and Market Law 2016, 164. With regard to user-review tools, the proposal has been largely inspired by the international debate that has led to the adoption of the ISO Standards on Online Consumer Reviews published in 2018.

77 See C. Busch, 'Reputational Feedback Systems', in Busch et al (eds), n 22 above, 77-84. The Draft has been converted into a proposal for Model Rules, currently under discussion. 
cated regulatory initiative focused on online platforms, these standards could largely improve the quality of enforcement in existing legislation on misleading advertising and unfair commercial practices in the area of online reputation systems.

The expansion of regulatory answers beyond the consumer domain would also be very important. Even acknowledging the specific vulnerability of consumers and their higher exposure to cognitive biases, the power of review tools in the concrete functioning of the market would suggest that a dedicated and more general scope for regulatory intervention would be useful to ensure transparency not only for the benefit of consumers but also in favour of businesses, both as purchasers and as suppliers. Indeed, the risk of unfair competition by deceptive business reviewers would increase rather than reduce the need for monitoring tools, at least by means of codes of conduct and peer monitoring. Relying on national unfair competition law would not sufficiently support the functioning of the internal market, due to the high fragmentation of Member States' law in this regard. ${ }^{78}$ The use of BtoB platforms as means for sharing knowledge and facilitating cooperative learning would largely benefit from a regulated system of buyers' reviews and would probably need a dedicated set of standards due to foster both transparency and cooperation.

\section{III.3 New Business Models and the Construction of Liability Rules: a missed Opportunity in both 'dedicated' and 'adapting' EU Digital Legislation}

The digital revolution is generating new business models based on totally different modes for matching supply and consumption. New intermediaries facilitate this matching through digital technologies and new opportunities are available for businesses, including SMEs. It is not always clear whether the use of digital technologies results into a shortening of the supply chain, enabling a more direct relationship between supplier and purchaser. It is more likely that the use of internet may create some degree of opaqueness in such relationships in respect of roles and liabilities of the actors involved. Does current legislation provide the tools for identifying duties and liabilities for any single player in the digital markets? If ever the need for a legislative intervention emerged at the EU level, should it be confined in the area of consumer protection?

78 See Renda, Cafaggi and Pelkmans, n 72 above, 37. 
Whereas national contract law would be ready to rely on the most diversified doctrines to address the platform's liability issue, ${ }^{79}$ an EU harmonized rule would significantly contribute to the increase of consumer trust in online trade, preventing platforms' forum shopping should national courts take different approaches. ${ }^{80}$

As a matter of fact, the posed question does not fall into a vacuum. Both the ECommerce Directive, as dedicated legislation on digital trade applicable to PtoC and PtoB platforms, and the recent initiatives in the area of consumer protection provide some references on platforms' liability. ${ }^{81}$ Surprisingly, the just approved consumer sale and digital content supply directives do not. ${ }^{82}$

Indeed, for a long time, the E-commerce directive has contributed to the identification of areas of immunity for information society service providers, whose function is limited to the transmission or storage of information provided or received at the conditions therein established, as far as (a) the provider does not have actual knowledge of illegal activity or information and, as regards claims for damages, is not aware of facts or circumstances from which the illegal activity or information is apparent; or (b) the provider, upon obtaining such knowledge or awareness, acts expeditiously to remove or to disable access to the information (Article 14 Directive 2000/31/EC). ${ }^{83}$ The Court of Justice has applied these rules to online platforms, distinguishing between platforms having an active role in promoting and assisting parties so to have control over data exchanged, and platforms keeping a 'neutral' position within the supplier-buyer relationship, therefore acting as 'mere intermediaries' ${ }^{84}$ The Court helps to identify the boundaries

79 This analysis would go beyond the scope of this article, focused on legislative approaches taken at the EU level. Comparative legal analysis could interestingly be developed considering, among others, the agency doctrines and the third party beneficiary contract doctrines as well as, in the area of torts, doctrines of vicarious liability.

80 Out of Europe, a US court has already concluded that a worldwide operating platform, playing an active role in the sale process, may not be denied the role of a seller from a liability perspective. See Oberdorf v Amazon.com Inc, No 18-1041 (3d Cir 2019).

81 On the former, see Tereszkiewicz, n 15 above, 905.

82 They only acknowledge that the platform may act as a direct seller or supplier and in that case the Directives apply to them; see recitals (18) and (23) in EU/2019/770-771 Directives, respectively. 83 See however in most recent caselaw: CJEU, 3 October 2019, Case C 18/18, Eva GlawischnigPiesczekv Facebook Ireland Limited, para 25, concluding that a host provider may be the addressee of injunctions adopted on the basis of the national law of a Member State, even if it satisfies one of the alternate conditions set out in Article 14(1) of Directive 2000/31, that is to say, even in the event that it is not considered to be liable.

84 ECJ, 23 March 2010, Joined Cases C-236/08 to C-238/08, Google v Louis Vuitton; CJEU, 12 July 2011, C-324/09, L'Oréal SA et al v eBay International AG, para 112 et seq. See Lodder, n 15 above, 33 et seq. On applicability of the EC/2000/31 Dir to platforms see Narciso, n 66 above, 566 et seq. 
of the immunity rule defined under the E-Commerce directive taking in due consideration the role of the platform within the trading chain. The level of responsibility increases (and immunity decreases) as far as 'neutrality' leaves space for an 'active' role and some form of control.

More recent caselaw helps to deepen the notion of 'control' across the several nuances of modern platforms. So, eg, while concluding that Uber Pop is a transport business, ${ }^{85}$ in the more recent Airbnb case the Advocate General confirms that, looking at power intensity, some degree of control is totally compatible with the characterisation of platforms as intermediaries. ${ }^{86}$

While taking this caselaw into consideration, the interpreter should acknowledge that the question of platform liability may not be limited, nor probably solved, by only looking at Articles 12-15 2000/31/EC Directive. Liability does not always concern contents and information stored or transmitted. Moreover, the scope of exemption should be linked with the objective pursed by EU law. If the exemption provided by the E-Commerce Directive is totally consistent with the aim of building the information society service market at the time of Directive's adoption, the complexity of the current digital market calls for new approaches. ${ }^{87}$ Questioning whether a platform qualifies as either a mere intermediary or a supplier does not suffice from a liability perspective. Different degrees of intermediation are combined with some degree of control over the business and the specific transactions involved and this has an impact on liability on a case by case basis. ${ }^{88}$ A platform could have control over quality or delivery standards, while remaining 'neutral' on IPR monitoring. So, it would be too simplistic concluding that Uber Pop (and maybe not other forms of platforms in the Uber environment) is always liable in case of breach of the transport contract, while Airbnb is never so.

Almost twenty years after the adoption of the E-Commerce Directive, an opportunity has been missed to define the duties and liabilities of online platforms in dedicated legislation. This would have allowed us to clarify the role of platforms among the many ones emerging along the line that runs between the two poles of neutrality and full control and to design the liability rules accordingly.

85 For a different view, see M.Y. Schaub, 'Why Uber is an information society service' Journal of European Consumer and Market Law 2018, 109.

86 Opinion of AG Szpunar, C-390/18, para 75.

87 G. Frosio, 'Reforming Intermediary Liability in the Platform Economy: A European Digital Single Market Strategy’ 112 Northwestern University Law Review 19 (2017); Cauffman, n 16 above, 239; De Franceschi, $\mathrm{n} 16$ above, 3.

88 In this regard the proposed approach differs from the one taken in the ELI Draft Model Rules, where platform's liability is made dependent on the 'predominant influence' had by the platform over the supplier. See M. Pecyna, 'Liability of the Platform Operator for Non-Performance of Suppliers', in C. Busch et al (eds), n 22 above, 157-165. 
Practice shows that business models are not binary and call for a more complex approach to liability, where joint and several liability plays an important role.

Even assuming that the time has come for EU dedicated legislation on digital trade that addresses platforms' liability for breach of the underlying contract, consumer protection legislation would continue to play an important complementary role. ${ }^{89}$ Not only would consumers benefit considerably from a clear indication of cases in which their rights could be enforced vis à vis the platform. They would also need to be aware of the type of protection they would enjoy or loose whenever enforcement shall be directed vis à vis a different (and remote) supplier, being this a professional or not; they would need to know whether, despite the presence of a distinct seller, some obligations are directly or jointly taken on by the platform or third parties (eg, delivery or monitoring over payment systems), or whether dispute resolution mechanisms are offered by the platform and to what extent these have an impact on remedies to be enforced vis à vis the seller.

In all these respects, consumer law is being adapted to the new challenges of digital markets. So, the OIS Regulation obliges the OIS providers to ensure that the identity of the business user providing the goods or services is clearly visible. ${ }^{90}$ Moreover, the proposed provisions integrating the UCPD and the CRD would oblige the platform to inform consumers whether the third party supplier is a trader 'on the basis of the declaration of that third party to the online marketplace' and that, if it is not, consumer protection does not apply. ${ }^{91}$ It is worth mentioning that the trader's identity falls within the information due before the distance contract conclusion under Article 6 CRD. ${ }^{92}$

Applying the rule already identified by the CJEU for offline trade as adapted to this different context, one should also conclude that an intermediary shall take full responsibility for the transaction as far as it does not inform the other party that it is acting on behalf of another person, being this a professional or a private party. ${ }^{93}$

Moreover, the proposed reform of the CRD establishes that consumers should be informed on how the obligations related to the contract are shared between the third party offering the goods, services or digital content and the provider of the online marketplace; the proposed text also acknowledges that, regardless this information, marketplace and third party may still be held responsible in relation to

89 See also C. Twigg-Flesner, Bad Hand? The "New Deal” for EU Consumers, available at https:// warwick.ac.uk/services/library/staff/warwick-research-publications.

90 Art 3.5 OIS Regulation.

91 See the proposed art 7(4)(f) UCPD and art 6a(1)(b, c) CRD.

92 See CJEU, 10 July 2019, Case C-649/17, BVV v Amazon EU Sàrl.

93 CJEU, 9 November 2016, Case C-149/15, Wathelet, 45. 
the contract under Union or national law. ${ }^{94}$ Therefore, platforms may 'share' suppliers' contractual obligations and may be held liable in other ways in relation to the contract. ${ }^{95}$

The grounds for these liabilities are not clarified, nor their extent, but the 'immunity veil' is pierced.

\section{Concluding Remarks}

The above analysis shows that the growth of digital markets may benefit considerably from the adoption of dedicated legislation on online platforms' contracting. Moving from this perspective, three issues have been examined: unfair terms and trading practices enacted by online platforms, the use of ranking and users' reviewing tools, platforms' liability for breach of buyers' rights. On these aspects EU institutions have taken legislative initiatives, partly adapting existing consumer law to the digital turn, partly working on dedicated legislation focused on online trade.

In both cases, the approach is still very dependent on the distinction between BtoC and BtoB relations: on the one hand, the professional role of intermediation service providers is acknowledged; on the other, situations, in which the professional status of online sellers/purchasers is hybrid or blurred, remain unexplored. Among emerging business models some exist in which the BtoC/BtoB divide is not distinctive, while legal issues linked with lack of transparency or other forms of unfairness still need to be addressed. In these cases, adapting existing consumer law is not sufficient; neither advisable would then be to fill the gaps only targeting the professional status of online traders. The analysis above suggests, for example, that the EU/2019/1150 Regulation could have been usefully extended to relations between online platforms and non-professional suppliers. Moreover, special attention should have been paid to different types of power unbalances between platforms and suppliers, considering power as a factor influencing the need for protection of weaker parties rather than an element calculated to obscure

94 See, eg, obligations imposed upon short-term rental platforms by national law (C. Busch, 'Regulating Airbnb in Germany - status quo and future trends' Journal of European Consumer and Market Law 2019, 39; A. Martínez Nadal, ‘Regulating Airbnb in Spain' Journal of European Consumer and Market Law 2019, 42).

95 See C. Twigg-Flesner, 'Disruptive Technology - Disrupted Law? How the Digital Revolution Affects (Contract) Law', in De Franceschi (ed), n 4 above, 37. For an application concerning the Airbnb model, V. Mak, 'Regulating online platform - The Case of Airbnb', in Grundmann (ed), n 4 above, 87-102, 90. 
the role of the platform as a market intermediary, on which the application of the new Regulation is based. The possible implications of the Uber jurisprudence, developed with totally different aims, should have been taken into account when defining the scope of application of the OIS legislation.

In some cases, the BtoC/BtoB divide is still very useful and should be maintained. It should apply, for example, when the question arises as to whether and vis à vis whom online purchasers should enjoy consumer rights. Here, legislation and caselaw should not only fight against the opaqueness brought by online intermediation, therefore adding information duties and transparency requirements (as explored in current proposals for reform of the CRD); but it should also clarify when and under which conditions intermediation implies a duty to monitor trading practices and therefore liability, including liability towards consumers. So far, the E-Commerce directive has favoured a binary approach in which 'neutral' intermediation would come with immunity and control with liability. Current developments show that many situations exist in which intermediation is in place together with control (or some degrees of control). Even if this role will not necessary transform a platform into a provider of goods and services, so that the intermediation veil may be partially preserved, still liability may arise depending on the type and degree of control on the contested violation.

Digital private law is taking the first steps into the internal market. Whereas national private law will continue to provide the general framework for private law matters arising in the internet and may certainly contribute to define model rules for ad hoc legislation on digital trade, the EU legislation is due to play a major role in many respects, such as, eg, transparency requirements, unfair terms and trading practices, liability regimes. Even more urgent would be to test the definition of online intermediation services against the one of 'control' and their implications for questions concerning the allocation of liability for the trade concerned or any contract failure in the platform. A demanding agenda for the years to come. 